UDC 662.73

\title{
TECHNOLOGY OF COMPLEX PROCESSING OF PEAT
}

\author{
Yu. Sniezhkin, Academician of the National Academy of Sciences of Ukraine, Doctor of \\ Technical Sciences, Professor \\ Zh. Petrova, Doctor of Technical Sciences, Senior Researcher \\ Yu. Novikova, postgraduate \\ A. Petrov, postgraduate \\ Institute of Engineering Thermophysics of NAS of Ukraine
}

E-mail: bergelzhanna@ukr.net

\begin{abstract}
Every country tries to be independent in everything, first of all it is necessary to have a high level of use of own energy resources. Due to the energy crisis, the transition from traditional energy sources to the integrated implementation of alternatives is relevant.

The purpose of the study is complex processing of peat for fuel and extraction of humic substances for fertilizer production.

Studies of extraction of humic substances were performed on a laboratory stand EI10, which reproduces the work of a pulsating dispersant with an active diaphragm. The classical technology of extraction of humic substances using chemical methods is based on high temperatures of the mixture, which requires high energy consumption. It was proposed mode of extracting humic component developed by the standard rules, but changes in temperature and duration of extraction processing in an alkaline solution cavitation device. The use of cavitation in the technology of obtaining humic preparations makes it possible to achieve their high physiological activity, high yield of water-soluble organic substances. Briquetting was used to increase the energy density of solid fuel.

Based on the research, the technology of obtaining humic fertilizers from peat was developed. The developed technology allows to be integrated into the existing production of the peat briquette plant and will allow to extract as much as possible humic substances from peat with essential reduction of temperature and extraction time with the subsequent application of liquid fraction as fertilizer.
\end{abstract}

Key words: peat, humates, fertilizers, fuel, extraction

Introduction. Humic acids are the most important component of soil humus. The greater their content, the more fertile the soil. However, in the natural state, humic acids are insoluble in water and inaccessible to plants. They become available only after indirect action - soil mineralization, when they are reborn into simple mineral compounds. The use 
of humic substances in the agricultural sector provides an increase in yield by $25-40 \%$, three times accelerates the recovery of the humus layer of soils.

Due to increasing demand for humic preparations necessary to organize their industrial production on a large scale. This will allow the faster introduction of humic acids and other drugs based on them in industry and agriculture.

Analysis of recent researches and publications. Existing technological schemes have a number of serious shortcomings, namely: 1) the periodicity of the process and as a consequence the cumbersomeness of the hardware design, the difficulty of automation, low productivity of installations and high operating costs; 2) high heat consumption; 3) large product losses and low extraction factor of humic acids, 4) large waste solids after extraction of humic fertilizers.

Of course, if we ask the question of industrial production at the present level, we can only talk about a continuous process. The main difficulty in developing a continuous technology for producing humates or humic acids is the extreme duration of the process due to the low rates of diffusion of the active part of the alkaline reagent into solid particles and the formation of humates from solids into solution, as well as the very specificity of humic acids as high molecular weight organic acids with colloidal properties. In addition, the separation of unreacted raw materials from the humate solution is difficult, as crushed peat is particularly swollen and partially peptized in alkaline solution, forming a fairly stable suspension, which is very slow to settle, and it is almost impossible to filter.

Great difficulties also arise in the process of filtration and drying of humic acids. Hence the need to find ways to intensify the process as a whole and especially its first stage - the extraction of humic acids from raw materials in the form of soluble humates.

The purpose of the study - complex processing of peat for fuel and extraction of humic substances for fertilizer production.

Materials and methods. At the Institute of Engineering Thermophysics NAS of Ukraine based on the principle of discrete-pulse energy input (DPEI) and successfully used in various industries efficient technologies mixing, dispersion and extraction with different types of jet pulsation devices. Pulsation dispersants with an active diaphragm are 
used to carry out extraction processes from plant raw materials, which, due to the creation of a powerful cavitation effect on the dispersed phase, provide intensive separation of bioactive extractives into the volume of the solvent [1].

The experiments were performed on a laboratory stand EI-10, which reproduces the work of a pulsating dispersant with an active diaphragm in the modes of dispersion and extraction (pulse extractor with a single load of 101 ) is designed to study the kinetics of hydrodynamics and heat and mass transfer in homogenization, mixing and extraction operations in the treatment of aqueous mixtures of lowland peat in order to extract biologically active humic substances [2].

The classical technology of extraction of humic substances using chemical methods is based on high temperatures of the mixture of $120-130{ }^{\circ} \mathrm{C}$, which requires high electricity consumption. The mode of extraction of the humus component according to the developed standard regulations was proposed, but by changing the extraction temperature by $20{ }^{\circ} \mathrm{C}$, $60{ }^{\circ} \mathrm{C}$ and the duration of treatment with alkaline solution in the cavitation apparatus for $20 \mathrm{~min}, 40 \mathrm{~min}$ and $60 \mathrm{~min}$. The studies were performed on milling and dry peat [1].

Results and discussion. Humic substances were determined by method adapted to our conditions [1]. Before determining the humic component, a sample of peat was prepared, and humic acid was extracted from the sample with an appropriate concentration of alkali, followed by neutralization with acid solution. After neutralization, humic acids precipitated, the solution was filtered, dried and the total amount of humic substances was determined.

Figure 1 presents the results of the effect of extraction time on the yield of the humus component at a hydromodule of 1:15 with an alkali concentration of $1 \%$. The figure shows that with increasing extraction time to $20 \mathrm{~min}$, both milling and dry peat increases the yield of the humus component. After 20 minutes of treatment, there is no intensification of extraction. The maximum yield of humic substances at the duration of extraction is 20 minutes. This dependence at the corresponding modes is observed both in dry and in milling peat. The duration of treatment in the range of 40-60 minutes leads to partial destruction of organic matter and reduced yield of humic substances. Therefore, the 
treatment of peat with an alkaline solution with a given concentration should be carried out for 20 minutes.

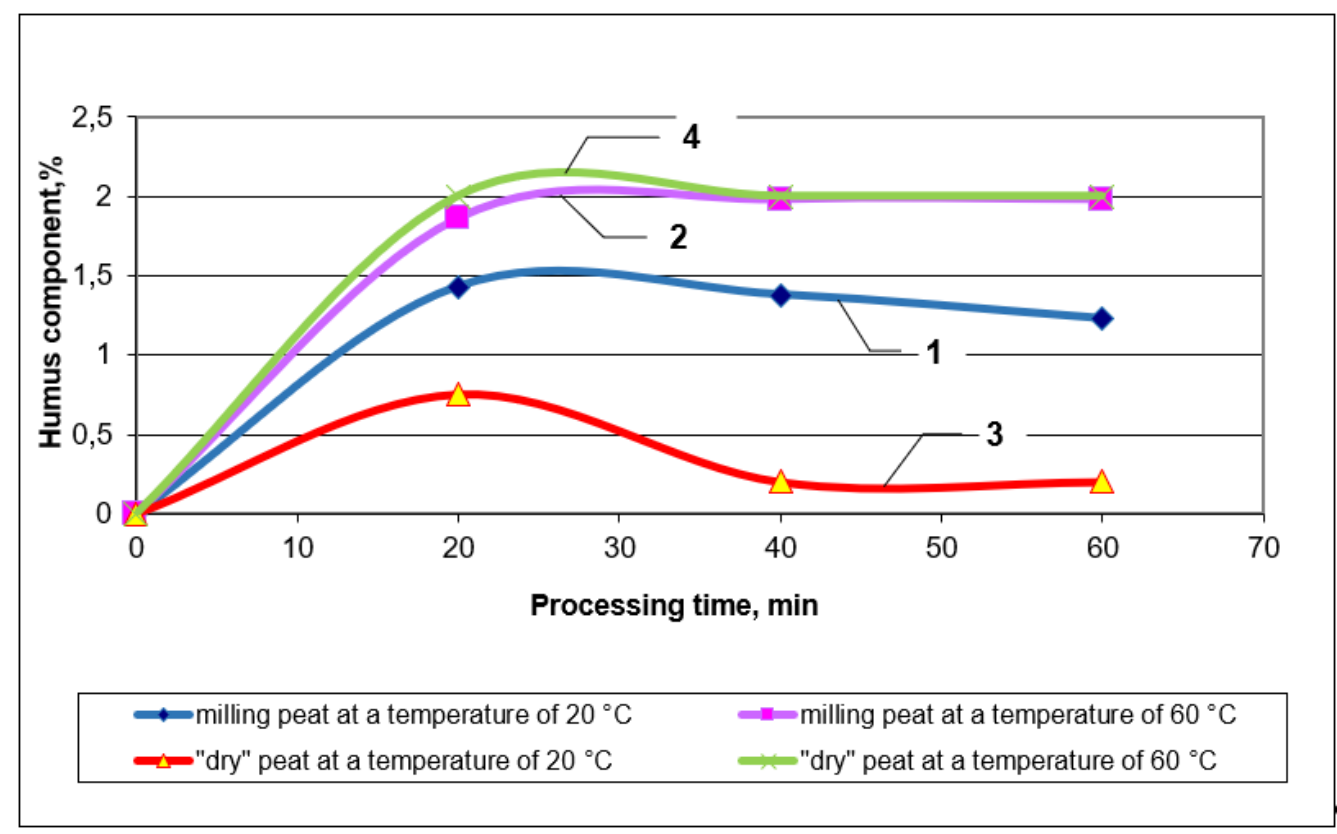

Fig. 1. The effect of extraction time on the yield of the humus component at a hydraulic module of $1: 15$ with an alkali concentration of $1 \%$ :

1 - milling peat at a temperature of $20^{\circ} \mathrm{C} ; 2$ - milling peat at a temperature of $60^{\circ} \mathrm{C}$;

3 - "dry" peat at a temperature of $20^{\circ} \mathrm{C} ; 4$ - "dry" peat at a temperature of $60{ }^{\circ} \mathrm{C}$

In the solid residue, humic substances are better determined experimentally at a treatment duration of $60 \mathrm{~min}$, but they do not pass into solution. This indicates that the alkali affects the release of humic substances, but this concentration is not enough for their transition to a solution from the solid phase. These changes occur only in milling peat, and on dry peat had an alkali concentration of $1 \%$ had no effect at all.

Based on preliminary data, studies on the extraction of humic substances were performed with a change in alkali concentration. Figure 2 presents the results of the study of the effect of alkali concentration on the yield of the humus component in the solution. With a change in the concentration of alkali solution of $1 \%, 3 \%$ and $5 \%$, the extraction of humic substances intensifies 1.2 times compared to $1 \%$. In dry peat this process is more intense than in milling peat. The concentration of alkali in the extraction of humic substances 3\% and 5\% differ insignificantly. But with increasing concentrations to 5\%, 
more sodium hydroxide is required, which changes the $\mathrm{pH}$ of the medium and increases the cost of production. Therefore, it is advisable when extracting humic substances, depending on the purpose of use, to extract the humic component from 1 to $3 \%$ alkali [3].

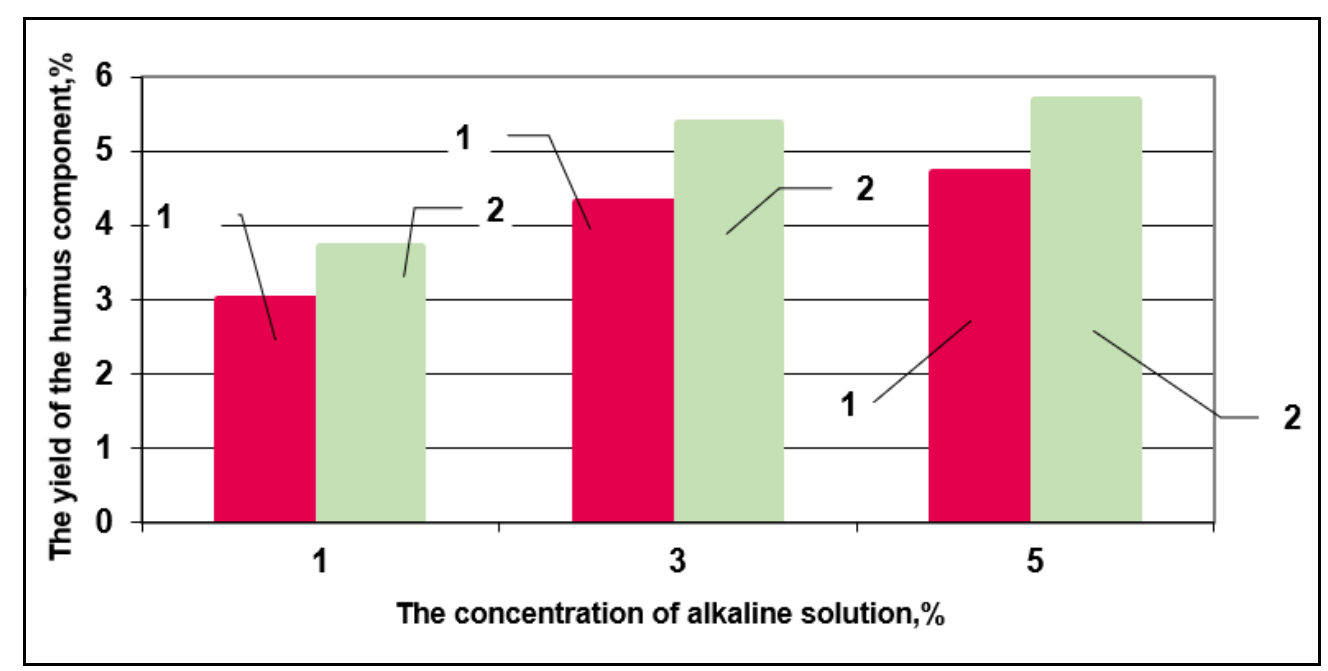

Fig. 2. The effect of alkaline solution concentration on the yield of the humus component:

1 - milling peat at a temperature of $20^{\circ} \mathrm{C} ; 2$ - "dry" peat at temperatures of $20^{\circ} \mathrm{C}$

After conducting research on traditional technology with changes in temperature, time and alkali concentration, the optimal extraction parameters were determined. It was also proposed to use, instead of traditional hydromechanical devices, homogenization.

A portion of dry or milled peat is loaded into the receiving tank of the device, filled with $1 \%$ alkali in a ratio of $1: 15$, the total volume of the mixture is 10 liters. During homogenization, the solid dispersed phase is destroyed, humic substances are removed from the peat, and the components of the mixture are mixed. The mixture was treated for $20 \mathrm{~min}$ at $60{ }^{\circ} \mathrm{C}$ and $1 \%$ alkali solution. These parameters were taken on the basis of previous studies. Samples of extracts of humic substances obtained by the traditional method were also taken for comparison. The research results are presented in Fig. 3. 


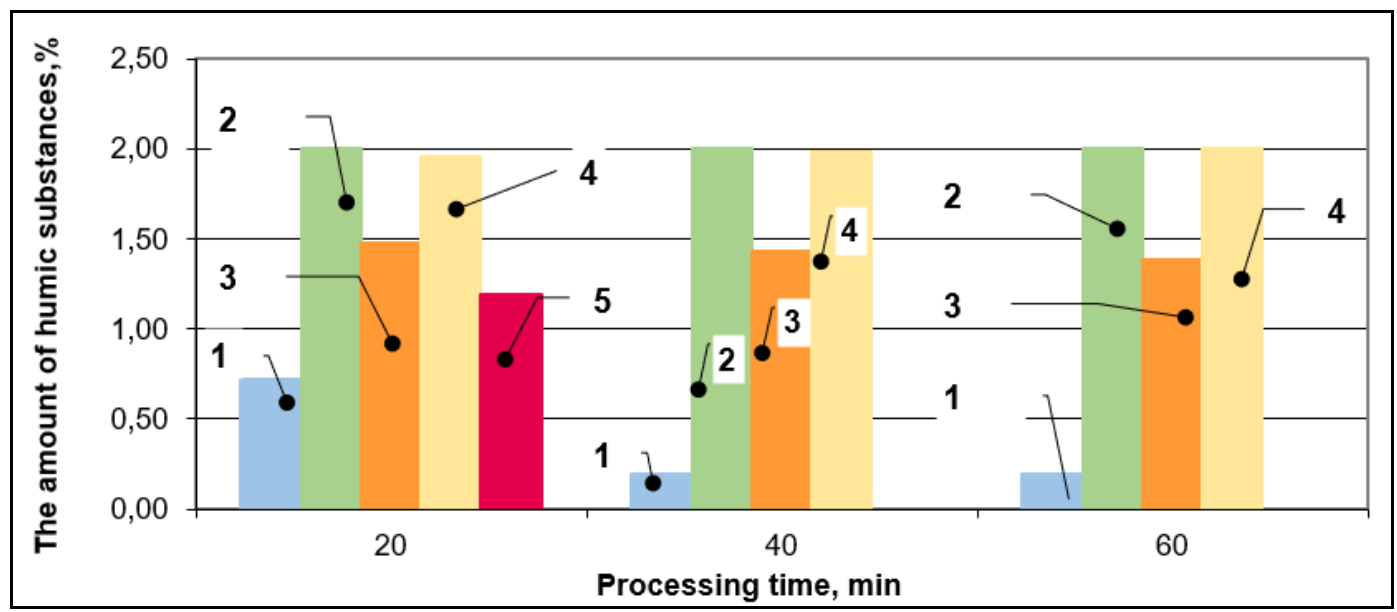

Fig. 3. Influence of mechano - heat treatment of peat on the yield of humus component:

1 - "dry" peat at a temperature of $20^{\circ} \mathrm{C} ; 2$ - "dry" peat at a temperature of $60{ }^{\circ} \mathrm{C}$; 3 - milling peat at a temperature of $20^{\circ} \mathrm{C} ; 4$ - milling peat at a temperature of $60{ }^{\circ} \mathrm{C} ; 5-$ control sample at a temperature of $133{ }^{\circ} \mathrm{C}$

As can be seen from Figure 3, the lowest yields of humic substances at an extraction temperature of $20^{\circ} \mathrm{C}$, in dry peat extraction is more intense. For comparison, the control sample obtained by traditional extraction technology at a temperature of $133^{\circ} \mathrm{C}$ was examined.

One of the factors that intensify this process is the temperature. Heating the peatalkaline suspension to a temperature of $60{ }^{\circ} \mathrm{C}$ can significantly increase the rate of formation and dissolution of humates.

Mechanical dispersion of peat in an alkaline environment can significantly intensify the process of extraction of humic acids from peat and can be used as a basis for the technological process in combination with subsequent heating of the finely dispersed peatalkaline suspension to a temperature of $60^{\circ} \mathrm{C}$. This will reduce the duration of the process of treatment of peat with an alkaline solution to $20-60$ minutes and extract at a lower consumption of alkali, ie with a ratio of peat: alkaline solution equal to 1:15.

Intensification of the process of humic acid extraction by combining fine dispersion of peat in an alkaline medium with subsequent heating of the mixture to a temperature of $60{ }^{\circ} \mathrm{C}$ with vigorous stirring provides a basis for the development of a continuous 
technological scheme for the production of humates. As a reagent used $1 \%$ solution of $\mathrm{KOH}$.

Based on the research, the technology of obtaining humic fertilizers from peat was developed and briquetted composite fuel was developed. The developed technology allows to be integrated into the existing production of the peat briquette plant. It involves field drying of peat, obtaining milled peat with additional grinding and sifting. The prepared and dried milling peat is extracted according to the presented scheme of Fig. 4.

The prepared raw material enters the extraction site where the alkali treatment of a given concentration. After that, the mixture enters the area of the thermostat. Liquid and solid phases are released at the treatment site. Liquid humic fertilizers are cleaned and packaged. The solid residue after receiving fertilizers enters the area of the blanks peat mixture (peat + solid residue after extraction) where it is obtained composite briquettes.

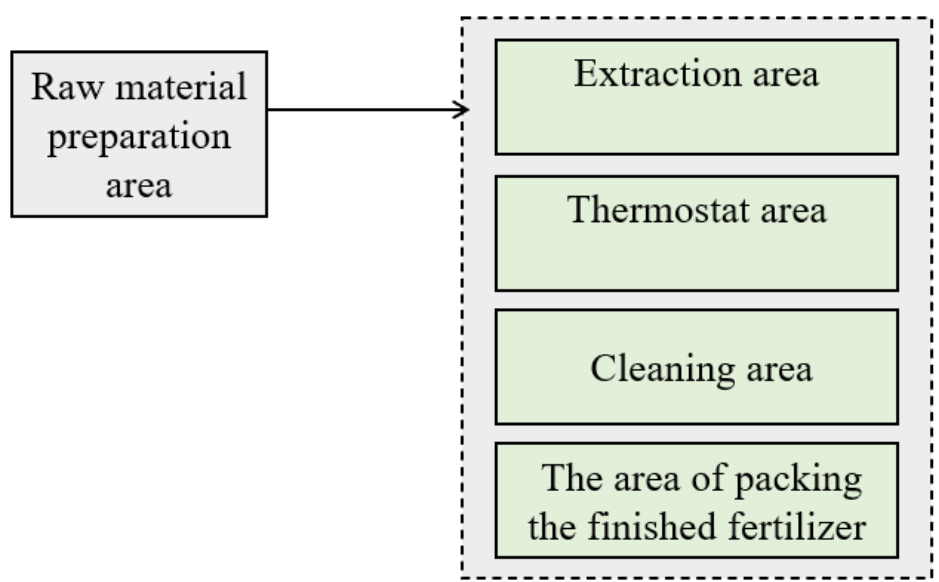

Fig. 4. Technology of complex processing of peat into humic fertilizers

The disadvantage of both raw peat and vegetable raw materials when using them as fuel is low energy density. Even with a sufficiently high heat of combustion, the fuel has a bulk density of an average of $200-300 \mathrm{~kg} / \mathrm{m}^{3}$ and requires briquetting.

Briquetting or granulation increases the bulk density to $850-950 \mathrm{~kg} / \mathrm{m}^{3}$. Accordingly, the energy density increases by 3 - 4 times and the impact of transport costs on price formation decreases. Fuel from the local category is transferred to the level of fuels that can be transported within Ukraine, competing with traditional [4]. 
Conclusions and perspectives. The use of humic substances in the agricultural sector provides an increase in yield by $25-40 \%$, three times accelerates the recovery of the humus layer of soils. The developed technology will allow to remove as much as possible humic and humic substances from peat with a significant reduction in temperature and extraction time with the subsequent use of the liquid fraction as fertilizer, and the solid residue - after extraction to produce cheap fuel. Compared to other types of composite biofuels, the resulting composite biofuel contains significantly less sulfur and ash. When burned, it emits almost no toxic substances and, accordingly, does not pollute the environment.

\section{References}

1. Petrova, Zh. O. (2016). Doslidzhennia rezhymiv ekstrahuvannia humusovykh ta huminovykh rechovyn [Research of extraction modes of humic and humic substances]. Scientific works, 47(2), 190-194.

2. Chaika, O.I., Hozhenko, L.P., Ivanytskyi, H.K., Korinchuk, D.M. (2012). Intensyfikatsiia protsesu dysperhuvannia nyzynnoho torfu iz zastosuvanniam pulsatsiinoho dysperhatora [Intensification of the process of dispersing lowland peat with the use of pulsating dispersant.]. Industrial heating technology, 35(5), 22-28.

3. Petrova, Zh., Vyshnevskyi, V., Novikova, Yu (2019). Nonwaste technology of receipt of humic fertilizers from peat. Proceedings of the 2nd International Scientific Conference. Chemical Technology and Engineering. Lviv (Ukraine), 278-279.

4. Korinchuk, D. M. (2012). Optymizatsiia parametriv vyhotovlennia kompozytsiinoho biopalyva $\mathrm{z}$ vykorystanniam torfu yak viazhuchoho [Optimization of composite biofuel production parameters using peat as a binder]. Industrial heating technology, 34(3), 73-77.

\section{Список використаних джерел}

1. Петрова Ж. О. Дослідження режимів екстрагування гумусових та гумінових речовин. Наукові праці ОНАХТ. 2016. № 47. Том 2. С. 190-194.

2. Чайка О. І., Гоженко Л. П., Іваницький Г. К., Корінчук Д. М. Інтенсифікація процесу диспергування низинного торфу із застосуванням пульсаційного диспергатора. Промышленная теплотехника. 2012. Т. 35. № 5. С. 22-28.

3. Zh. Petrova, V. Vyshnevskyi, Yu. Novikova. Nonwaste Technology of Receipt of Humic Fertilizers from Peat. Chemical Technology and Engineering: Materials of the 2nd International Scientific Conference (Ukraine, Lviv, June 24-28th, 2019). Lviv: Lviv Polytechnic National University, 2019. Pp. 278-279.

4. Корінчук Д. М. Оптимізація параметрів виготовлення композиційного біопалива 3 використанням торфу як в'яжучого. Промышленная теплотехника. 2012. Т. 34. № 3. C. $73-77$. 


\title{
ТЕХНОЛОГІЯ КОМПЛЕКСНОЇ ПЕРЕРОБКИ ТОРФУ
}

\author{
Ю. Ф. Снежкін, Ж. О. Петрова, Ю. П. Новікова, А. І. Петров
}

Анотація. Кожна країна намагається бути незалежною у всьому, в першу чергу для иього потрібно мати високий рівень використання власних енергетичних ресурсів. У зв'язку з енергетичною кризою актуальним є перехід від традиційних джерел енергї̈ до комплексного впровадження альтернативних.

Мета дослідження комплексна переробка торфу на паливо та екстрагування гумінових речовин на виробництво добрив.

Дослідження екстрагування гумінових речовин проводили на лабораторному стенді ЕI-10, щео відтворює роботу пульсаиійного диспергатора з активною діафрагмою. Класична технологія екстрагування гумусових речовин із використанням хімічних методів базується на високих температурах суміші, щуо вимагає великих витрат електроенергії. Був запропонований режим екстрагування гумусової складової за розробленим стандартним регламентом, але зміною температури екстрагування та тривалістю обробки лужним розчином в кавітаційному апараті. Використання кавітаиії в технологіях отримання гумінових препаратів дає можливість досягнення їх високої фізіологічної активності, великого виходу водорозчинних органічних речовин. Для збільшення енергощільності твердого палива використано брикетування.

На основі проведених досліджень була розроблена технологія отримання гумінових добрив з торфу. Розроблена технологія дозволяє інтегруватися в існуюче виробництво торфобрикетного заводу та дозволить максимально витягувати гумінові речовини з торфу з істотним зменшенням температури і часу екстракції з подальшим застосуванням рідкої фракиії в якості добрива.

Ключові слова: торф, гумати, добрива, паливо, екстракція

\section{ТЕХНОЛОГИЯ КОМПЛЕКСНОЙ ПЕРЕРАБОТКИ ТОРФА Ю. Ф. Снежкин, Ж. А. Петрова, Ю. П. Новикова, А. И. Петров}

Аннотация. Каждая страна пытается быть независимой во всем, в первую очередь для этого нужно иметь высокий уровень использования собственных энергетических ресурсов. В связи с энергетическим кризисом актуальным является переход от традиционных источников энергии $\kappa$ комплексному внедрению альтернативных.

Цель исследования - комплексная переработка торфа на топливо и извлечения гуминовых веществ на производство удобрений.

Исследование извлечения гуминовых веществ проводили на лабораторном стенде ЭИ-10, который воспроизводит работу пульсаиионного диспергатора с активной диафрагмой. Классическая технология извлечения гумусовых веществ с использованием химических методов базируется на высоких температурах смеси, требует больших затрат электроэнергии. Был предложен режим извлечения гумусовой составляющей по разработанному стандартному регламенту, но с изменением температуры экстрагирования и продолжсительностью обработки щелочным раствором в кавитационном аппарате. Использование кавитации в технологиях получения гуминовых препаратов дает возможность достижения их 
"Енергетика і автоматика", №5, 2020 р.

высокой физиологической активности, большого выхода водорастворимых органических веществ. Для увеличения энергоплотности твердого топлива использовано брикетирование.

На основе проведенных исследований была разработана технология получения гуминовых удобрений из торфа. Разработанная технология позволяет интегрироваться в существующее производство торфобрикетного завода $u$ позволит максимально извлекать гуминовые вещества из торфа с существенным уменьшением температуры и времени экстракции с последующии применением жидкой фракиии в качестве удобрения.

Ключевые слова: торф, гуматы, удобрения, топливо, экстракция 